\title{
Job satisfaction among community health workers in Zahedan District, Islamic Republic of Iran
}

A. Kebriaei ${ }^{1}$ and M.S. Moteghedi ${ }^{1}$

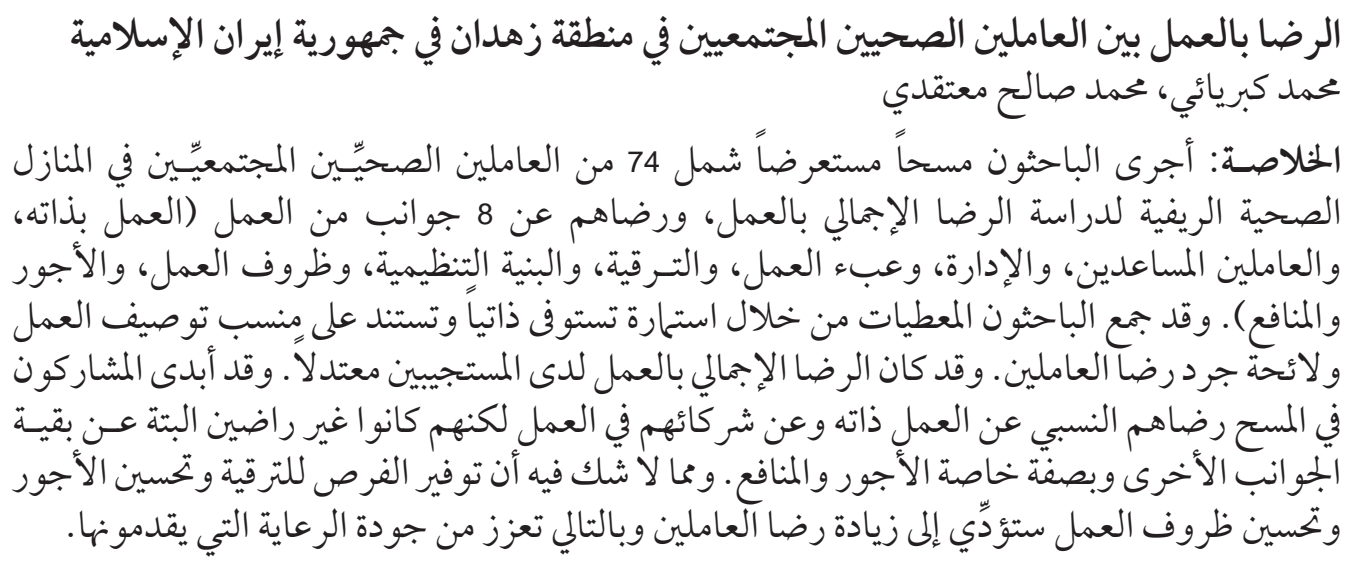

ABSTRACT We conducted a cross-sectional survey among 74 community health workers in rural health houses to investigate overall job satisfaction and satisfaction with 8 aspects of the job (work itself, co-workers, management, workload, promotion, organizational structure, working conditions, and payment and benefits). Data were collected by a self-administered questionnaire based on the Job Descriptive Index and the Employee Satisfaction Inventory. Overall job satisfaction of respondents was moderate. They were satisfied with the work itself and co-workers, but very dissatisfied with all other aspects, especially payments and benefits. Providing opportunities for promotion and improving payments and work conditions would increase overall job satisfaction and promote quality of care.

Satisfaction au travail chez les agents de santé communautaires du district de Zahedan (République islamique d'Iran)

RÉSUMÉ Nous avons réalisé une étude transversale auprès de 74 agents de santé communautaires exerçant dans des dispensaires ruraux afin d'évaluer leur satisfaction au travail, à la fois globale et sous huit aspects différents (travail en lui-même, collègues, hiérarchie, charge de travail, promotion, structure organisationnelle, conditions de travail, et rémunération et avantages). Les données ont été recueillies grâce à un autoquestionnaire établi à partir des indices de satisfaction professionnelle Job Descriptive Index et Employee Satisfaction Inventory. La satisfaction globale des personnes interrogées était modérée. Ces personnes étaient satisfaites du travail en lui-même et de leurs collègues, mais très insatisfaites en ce qui concerne tous les autres aspects, en particulier la rémunération et les avantages. Des possibilités de promotion et une amélioration des rémunérations et des conditions de travail augmenteraient la satisfaction professionnelle globale et renforceraient la qualité des soins.

${ }^{1}$ Public Health Department, School of Health, Zahedan University of Medical Sciences, Zahedan, Islamic Republic of Iran (Correspondence to A. Kebriaei: kebria_noosh@yahoo.com).

Received: 10/02/07; accepted: 04/06/07

المجلة الصحية لشرق المتوسط، منظمة الصحة العالمية، المجلد الخامس عشر، العدد 0، 9 . ب 


\section{Introduction}

Work plays a prominent role in our lives. It occupies more time than any other single activity and provides the economic basis for our lifestyle. Therefore, job satisfaction is a key research area for numerous specialists and is one of the most frequently studied work attitudes [1].

Job satisfaction is defined as how people feel about their jobs and job components [2]. That is, it is the discrepancy between what an employee values and what the situation provides. Research has demonstrated the importance of job satisfaction to an organization in terms of its positive relationship with individual performance, productivity, employee relations, physical and mental health and life satisfaction [3-7].

Conversely, it can be argued that job dissatisfaction has negative impacts on the organizational structure and work flows of establishments, such as greater nonconformance to procedures and policies and employee absence and turnover, decline in productivity, increases in work accidents, deterioration of mental and physical health, and intra-organizational conflict [3,4,8-10].

Therefore, apart from its humanitarian utility, if an organization is really interested in the most effective use of all resources (including labour), then it is important to maximize employee productivity by considering and addressing the factors that compromise their job satisfaction [11].

Previous studies have shown that low job satisfaction is a major cause of turnover among health care providers $[12,13]$. In addition, job satisfaction may affect the quality of services and organizational commitment [14-16] and may be a contributing factor to shortages of health care providers [17].

As far as we are aware, no research has addressed job satisfaction among Iranian community health workers (CHWs). Therefore the main aims of this study were to investigate job satisfaction levels overall and in various areas among health care workers in our community and to suggest approaches that could improve job satisfaction.

\section{Methods}

\section{Study population}

A cross-sectional study was conducted in May 2005. The population for the study comprised all $76 \mathrm{CHWs}$, called behvarz in Farsi, who work at the 44 rural health houses in Zahedan district, Sistan va Baluchestan province, Islamic Republic of Iran. In rural areas the first point of contact with health services is the "health house" located in villages covering 500 to 1500 people [18]. Thus the CHWs provide primary health care services for the villagers attending the health house.

\section{Data collection}

CHWs (76) were asked to complete a selfadministered questionnaire which was collected immediately after completion. A total of 74 usable questionnaires were returned, giving a response rate of $97.4 \%$. Researchers informed all CHWs that their participation was voluntary and that individual responses would be held in confidence.

The questionnaire was based on 2 widely adopted instruments, the Job Descriptive Index (JDI) [19] and the Employee Satisfaction Inventory (ESI) [20]. A pilot test was undertaken with $10 \mathrm{CHWs}$. This allowed us to improve some of the questions and arrive at the final version of the questionnaire.

Respondents were asked to provide demographic information including age, sex, education level and length of service in present job. In addition to the demographic data, the questionnaire included a single 
item regarding overall job satisfaction and 42 questions concerned with 8 aspects of the job including: the work itself, working conditions, workload, wages and benefits, management, co-workers, organizational structure and promotion.

Respondents were asked to indicate the level of satisfaction or dissatisfaction that they derived from each item of the 8 aspects of their jobs. The scale ranged from 1 to 5 with 1 = very dissatisfied, 2 = dissatisfied, $3=$ indifferent (neither satisfied nor dissatisfied), $4=$ satisfied and $5=$ very satisfied. Scores from items of the same dimension were computed to determine the sum of their dimension. For ease of analysis responses of 4 (satisfied) and 5 (very satisfied) were classified as "satisfied", those of 1 (very dissatisfied) and 2 (dissatisfied) as "dissatisfied". This resulted in a 3-category scale for data analysis and interpretation: satisfied, neutral and dissatisfied. For each aspect, workers were classified as being dissatisfied if the sum of the responses to the different items divided by the number of items was between 1 and 1.66. If the average value of the responses was between 1.67 and 2.33, the workers were classified as being neither satisfied nor dissatisfied, while if it was more than 2.33 the worker was classified as satisfied.

Reliability analysis showed that the Cronbach alpha coefficient of the questionnaire was 0.87 , which was considered relatively high and internally consistent [21]. In this study, content validity was applied and the help of 2 experts in human resources management was enlisted.

Data from the questionnaire were analysed using the SPSS, version 13.0. Initially, descriptive statistics were carried out. Next, Spearman rho coefficients were computed for correlation between the 8 aspects of the job, and Kruskal-Wallis and MannWhitney $U$ tests were used to evaluate differences between sex, age group, marital status, education level and length of service with overall job satisfaction and satisfaction with the 8 aspects of the job.

\section{Results}

Of the 74 respondents participating in this study, $68.9 \%$ were males and $93.2 \%$ were married. The mean age of the group was 32 (standard deviation 6.1 ) years: $39.2 \%$ were 30 years or younger, $47.3 \%$ were $31-40$ years and $13.5 \%$ were aged 41 years and above. Nearly $34 \%$ of the participants had worked for less than 5 years at their current workplace; $33 \%$ between 6 and 10 years, $16 \%$ between 11 and 15 years and $15 \%$ more than 15 years. As regards education, $14.5 \%$ of the CHWs had only completed primary education, around $50 \%$ had completed secondary education (between primary and high school) and $35.5 \%$ had a high school education.

Tables 1 and 2 present a summary of the responses to the job satisfaction questionnaire on 8 aspects of the $\mathrm{CHW}$ job and on the job overall. The mean scores for each aspect of the job ranged from 3.61 for the work itself to 1.93 for payment and benefits. The respondents were generally dissatisfied with their jobs with mean scores in 6 out of 8 identified aspects of the job of less than 3 . The results show that respondents were most satisfied with the work itself (mean $=3.61)$ and co-workers $($ mean $=3.45)$, but less satisfied with the other 6 .

Table 2 shows the percentage of respondents who were satisfied, dissatisfied with or indifferent to aspects of their jobs. It indicates that with the work itself, the percentage of the respondents who were satisfied was high $(70.3 \%)$. The respondents were least satisfied with payment and benefits, only $4.1 \%$ satisfied, with around 
Table 1 Average rating of respondents on the satisfaction or dissatisfaction derived from aspects of their jobs

\begin{tabular}{lcccc}
\hline Aspect of the job & Mean score & Median score & Modal score & $\begin{array}{c}\text { Standard } \\
\text { deviation }\end{array}$ \\
\hline Work itself & 3.61 & 4 & 4 & 0.77 \\
Co-workers & 3.45 & 4 & 4 & 0.86 \\
Management & 2.77 & 2 & 2 & 0.93 \\
Workload & 2.49 & 2 & 2 & 0.85 \\
Promotion & 2.34 & 2 & 2 & 0.74 \\
Organizational structure & 2.28 & 2 & 2 & 0.63 \\
Working conditions & 2.22 & 2 & 2 & 0.58 \\
Payment and benefits & 1.93 & 2 & 2 & 0.85 \\
Overall job satisfaction & 2.84 & 3 & 4 & 1.22 \\
\hline
\end{tabular}

\begin{tabular}{|c|c|c|c|}
\hline Aspect of job & $\begin{array}{c}\text { Satisfied } \\
\%\end{array}$ & $\begin{array}{c}\text { Dissatisfied } \\
\% \\
\end{array}$ & $\begin{array}{c}\text { Indifferent } \\
\% \\
\end{array}$ \\
\hline Work itself & 70.3 & 13.5 & 16.2 \\
\hline Co-workers & 60.9 & 20.3 & 18.8 \\
\hline Management & 27.0 & 51.4 & 21.6 \\
\hline Workload & 23.0 & 56.7 & 20.3 \\
\hline Promotion & 12.2 & 74.3 & 13.5 \\
\hline Organizational structure & 6.8 & 75.7 & 17.6 \\
\hline Working conditions & 5.4 & 81.1 & 13.5 \\
\hline Payment and benefits & 4.1 & 91.8 & 4.1 \\
\hline Overall job satisfaction & 40.5 & 47.3 & 12.2 \\
\hline
\end{tabular}

$92 \%$ of the respondents indicating that they were dissatisfied with this aspect.

A comparison of the distribution of responses on the separate job aspects shows that $\mathrm{CHWs}$ were on average satisfied with only 2 aspects of the job, i.e. the work itself $(70.3 \%)$ and co-workers $(60.9 \%)$. However, with the other 6 aspects, respondents were not satisfied, with the proportion dissatisfied ranging from $51.4 \%$ (management) to $91.8 \%$ (pay and benefits). In terms of overall satisfaction, $40.5 \%$ of the respondents were satisfied with their job.

The correlation between the different aspects was found to be significant (Table
3). These differences suggest that satisfaction was not independent of the individual job aspect.

The Mann-Whitney U test showed that the differences in overall job satisfaction and satisfaction with the 8 aspects of the job between males and females and between married and single individuals were not statistically significant. The Kruskal-Wallis test also indicated that there were no statistically significant differences between age group, education level and length of service with overall job satisfaction and satisfaction with the 8 aspects of the job. 


\begin{tabular}{lccccccc}
\hline \multicolumn{7}{l}{ Table 3 Correlation coefficients for aspects of job satisfaction } \\
\hline Aspect of the job & $\mathbf{1}$ & $\mathbf{2}$ & $\mathbf{3}$ & $\mathbf{4}$ & $\mathbf{5}$ & $\mathbf{6}$ & $\mathbf{7}$ \\
\hline Work itself & - & & & & & & \\
Co-workers & $0.40^{*}$ & - & & & & & \\
Management & $0.49^{*}$ & $0.55^{*}$ & - & & & & \\
Workload & $0.42^{*}$ & $0.47^{*}$ & $0.36^{*}$ & - & & & \\
Promotion & $0.39^{*}$ & $0.54^{*}$ & $0.25^{*}$ & 0.17 & - & & \\
Organizational structure & $0.34^{*}$ & $0.35^{*}$ & $0.47^{*}$ & $0.41^{*}$ & $0.34^{*}$ & - & \\
Working conditions & $0.39^{*}$ & $0.51^{*}$ & $0.48^{*}$ & $0.49^{*}$ & $0.41^{*}$ & $0.41^{*}$ & - \\
Payment and benefits & 0.14 & 0.20 & $0.34^{*}$ & $0.24^{*}$ & $0.34^{*}$ & $0.27^{*}$ & $0.37^{*}$ \\
\hline
\end{tabular}

${ }^{*}$ Correlation significant at $\mathrm{P}<0.05$.

\section{Discussion}

The findings of our study indicate that the proportion of respondents who were overall dissatisfied with their job is more than the proportion of those who were satisfied. While CHWs were very satisfied with a few aspects of their jobs, overall, they enjoyed only a moderate level of job satisfaction. These findings are in line with the study of Ofili and colleagues [22] but inconsistent with other studies [7,23-26].

Several noteworthy points emerged from our results (Table 2). First, a person can be relatively satisfied with some aspect of his or her job and dissatisfied with others, either because they fail to fulfil his or her needs and values or because they do not meet his or her expectations. Second, there is a clear need for improving management, workload, promotion opportunities, organizational structure, working conditions, and pay and benefits in the future as there was clearly dissatisfaction with these aspects.

We found the greatest dissatisfaction lay in payments and benefits. This finding is similar to those of other studies [25-27]. Naturally, personnel are sensitive to salary issues because of their impact on living standards and providing a sense of security [4]. Thus, a low level of salary satisfaction is a common problem among all types of employees [28]. Many managers believe that the key to motivating and satisfying service employees is to reward workers with money, bonuses or raises [29]. In this regard, it is suggested that health systems provide a suitable payment and fringe benefits scheme in order to satisfy CHWs and maintain their loyalty.

The low level of salary satisfaction among CHWs can also be explained in terms of the social comparison theory. Accordingly, a main concern when analysing people's satisfaction with their salary is identifying the referent used in the individual comparisons [28] and attempting to erase inequalities.

Working conditions in our study was one of the lowest rated aspects contributing to the CHWs' job satisfaction, similar to the findings of Bodur [25]. Other studies have concluded that a harmonious working environment is related to job satisfaction [30]. Working conditions must be suitable for personnel needs, their expectations and aspirations; this includes factors such as lighting, heating, air circulation and noise. This is important because working conditions and factors that affect them are the most important issues affecting productivity. In contrast, poor working conditions could cause physiological and psychological stress [4]. Thus, more attention should 
be paid to working conditions in order to increase CHWs' satisfaction with this aspect and hence their general satisfaction level.

Satisfaction with management and organizational structure was also low, which is similar to other studies [27,31]. Management types and communication possibilities with superiors are important to job satisfaction [32]. Consulting with CHWs and giving importance to their decisions and feelings will provide greater satisfaction. Some aspects of a CHW's attitude toward supervision and organizational structure, such as supervisor's willingness to stand by the CHW and fairness in organization, can only be changed by a noticeable shift in the management's behaviour. Other facets, such as recognition for a job well done, can be easily altered. It is far less expensive, and sometimes just as effective, to give recognition to an employee for a job well done as opposed to a pay raise [33].

Satisfaction with promotion is another aspect of the job that had a low rating by CHWs. Management should look into the reasons for this dissatisfaction and work to establish a transparent and equitable promotion system. This would likely increase job satisfaction and the productivity of personnel.

Respondents were also dissatisfied with the workload, mostly due to long working hours (morning and afternoon). More attention needs to be paid to this issue and modifications made to the workload in order to increase the satisfaction levels with this aspect.

Satisfaction with co-workers in our study was relatively high which is similar to other studies [26,27]. Good relations among colleagues and having the support of superiors and subordinates generally create a feeling of satisfaction. Research on social networks has also shown that social support from co- worker networks serves as a resource that affects job satisfaction [28].

In our study, satisfaction with the work itself was high, which is a positive finding. Because the work itself was enjoyable for the respondents, providing opportunities for promotion and improving pay and work conditions could significantly increase satisfaction with some aspects as well as overall job satisfaction of CHWs and lead to improved quality of care as a result.

In general, a number of strategies can be suggested that managers might pursue to increase job satisfaction among CHWs, as well as strategies to avoid. For example, establishing measures of job "success", and recognizing and celebrating employees who achieve these measures may increase the level of job satisfaction by creating a stronger link between behaviour, attitude and outcome. The issues that appear to make CHWs most dissatisfied with their job are the ones directly under the control of management. Thus managers of primary health care services should also shift their attention and resources to the 6 aforementioned critical facets of job satisfaction.

Whilst our findings contribute to our greater understanding of the CHWs' job satisfaction, there were some limitations to the study. The sample was relatively small and restricted to CHWs in Zahedan district. Consequently the findings may not be generalized to other districts or to other national and cultural contexts.

We hope that the study will impress upon managers and supervisors in health establishments the critical importance of job satisfaction and that promoting job satisfaction among CHWs may enable them to improve performance without incurring substantial additional costs, especially as the primary antecedents of job attitudes are within management's ability to influence [6]. 


\section{Acknowledgements}

We are grateful to the respondents who participated in the study and to Mrs Maryam Kebriaei for reviewing the manuscript.
We appreciate the support of the Zahedan Medical Science University authorities for this project.

\section{References}

1. Koustelios A. Personal characteristics and job satisfaction of Greek teachers. International journal of educational management, 2001, 15(7):354-8.

2. Chiu R, Francesco AM. Dispositional traits and turnover intention. International journal of manpower, 2003, 24(3):284-98.

3. Lam T, Baum T. Study of managerial job satisfaction in Hong Kong's Chinese restaurants International journal of contemporary hospitality management, 2001, 13(1):35-42.

4. Aksu AA, Aktas A. Job satisfaction of managers in tourism. Cases in the Antalya region of Turkey. Managerial auditing journal, 2005, 20(5):479-88.

5. Appleton K, House A, Dowell A. A survey of job satisfaction, sources of stress and psychological symptoms among general practitioners in Leeds. British journal of general practice, 1998, 48:1059-63.

6. Oshagbemi T. Academics and their managers: a comparative study in job satisfaction. Personnel review, 1999, 28(1/2):108-23.

7. Oshagbemi T. Overall job satisfaction: how good are single versus multiple-item measures? Journal of managerial psychology, 1999, 14(5):388-403.

8. Morgan R, McDonagh $\mathrm{P}$, Ryan-Morgan $T$. Employee job satisfaction: an empirical assessment of marketing managers as an occupationally homogeneous group. Journal of managerial psychology, 1995, 10(2):10-17.

9. Buchbinder SB et al. Primary care physician job satisfaction and turnover. Amer- ican journal of managed care, 2001, 7(77):701-13.

10. Hoogendoorn WE et al. High physical work load and low job satisfaction increase the risk of sickness absence due to low back pain: results of a prospective cohort study. Occupational and environmental medicine, 2002, 59:323-8.

11. Brunetto $Y$, Farr-Wharton R. Using social identity theory to explain the job satisfaction of public sector employees. International journal of public sector management, 2002, 15(7):534-51.

12. Curry $\mathrm{J}$ et al. Determinants of turnover among nursing department employees. Research nursing health, 1985, 8:397411.

13. Irvine D, Evans M. Job satisfaction and turnover among nurses: integrating research findings across studies. Nursing research, 1995, 44(4):246-53.

14. Yoder L. Staff nurses' career development relationships and self reports of professionalism, job satisfaction, and intent to stay. Nursing research, 1995, 44(5):290-7.

15. Beall $C$ et al. Job satisfaction of public health nurses: is there a predictable decline? Journal of health human services administration, 1994, 17(2):243-60.

16. MacRobert M, Schmele J, Henson R. An analysis of job morale factors of community health nurses who report a low turnover rate. Research journal of nursing administration, 1993, 23(6):22-7.

17. Goodell T, Van Ess Coeling H. Outcomes of nurses' job satisfaction. Journal of nursing administration, 1994, 24(11):36-41. 
18. Soori $\mathrm{H}$, Motlagh E. Iranian rural health workers (behvarz) and risk factors of childhood injury. Eastern Mediterranean health journal, 1999, 5(4):684-9.

19. Smith PC, Kendall LM, Hulin CL. The revised job descriptive index. Chicago, Rand McNally, 1985.

20. Koustelios A, Bagiatis, K. The employee satisfaction inventory (ESI): development of a scale to measure satisfaction of Greek employees. Educational and psychological measurement, 1997, 57:469-76.

21. Hair JF et al. Multivariate data analysis, 5th ed. Englewood Cliffs, Prentice-Hall, 1998.

22. Ofili AN et al. Job satisfaction and psychological health of doctors at the University of Benin Teaching Hospital. Occupational medicine, 2004, 54:400-3.

23. Antoniou AS, Davidson MJ, Cooper CL. Occupational stress, job satisfaction and health state in male and female junior hospital doctors in Greece. Journal of managerial psychology, 2003, 18(6):592-621.

24. Bennett S, Plint A, Clifford TJ. Burnout, psychological morbidity, job satisfaction, and stress: a survey of Canadian hospital based child protection professionals. Archives of disease in childhood, 2005, 90:1112-6.

25. Bodur S. Job satisfaction of health care staff employed at health centres in Turkey. Occupational medicine, 2002, 52(6):353-5.

26. Sibbald B et al. GP job satisfaction in 1987, 1990 and 1998: lessons for the future? Family practice, 2000, 17(5):36471.
27. Castle NG. An instrument to measure job satisfaction of nursing home administrators. BMC medical research methodology, 2006, 6:47.

28. Bonache J. Job satisfaction among expatriates, repatriates and domestic employees: The perceived impact of international assignments on workrelated variables. Personnel review, 2005, 34(1):110-24.

29. Snipesa RL et al. The effects of specific job satisfaction facets on customer perceptions of service quality: an employeelevel analysis Journal of business research, 2005, 58:1330-9.

30. Davis G. Job satisfaction survey among employees in small businesses. Journal of small business and enterprise development, 2004, 11(4):495-503.

31. Linzer M et al. Managed care, time pressure, and physician job satisfaction: results from the physician worklife study. Journal of general internal medicine, 2000, 15(7):441-50.

32. Kutanis R, Bayraktarog LS. Karayolu turizm tas, imacilig inda is, tatmini unsurlari: bir uygulama [Job satisfaction elements in highway transportation: an application]. Paper presented at the 1st Tourism Congress of Mediterranean Countries, Akdeniz University School of Tourism \& Hotel Management, Antalya, 17-21 April, 2002:604-19.

33. Richard MD et al. An investigation of the determinants of extrinsic job satisfaction among drivers. International journal of logistic management, 1994, 5(2):95106. 